\title{
A comparison of airway pressures for inflation fixation of developing mouse lungs for stereological analyses
}

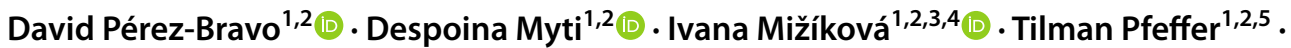

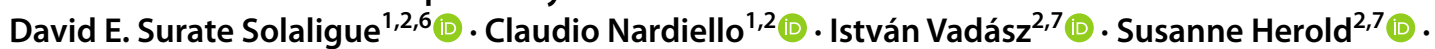 \\ Werner Seeger ${ }^{1,2,7,8}$ (D) Katrin Ahlbrecht ${ }^{1,2}$ (D) $\cdot$ Rory E. Morty ${ }^{1,2,7}$ (])
}

Accepted: 25 November 2020 / Published online: 29 December 2020

(c) The Author(s) 2020

\begin{abstract}
The morphometric analysis of lung structure using the principles of stereology has emerged as a powerful tool to describe the structural changes in lung architecture that accompany the development of lung disease that is experimentally modelled in adult mice. These stereological principles are now being applied to the study of the evolution of the lung architecture over the course of prenatal and postnatal lung development in mouse neonates and adolescents. The immature lung is structurally and functionally distinct from the adult lung, and has a smaller volume than does the adult lung. These differences have raised concerns about whether the inflation fixation of neonatal mouse lungs with the airway pressure $\left(P_{\text {aw }}\right)$ used for the inflation fixation of adult mouse lungs may cause distortion of the neonatal mouse lung structure, leading to the generation of artefacts in subsequent analyses. The objective of this study was to examine the impact of a $P_{\text {aw }}$ of 10,20 and $30 \mathrm{cmH}_{2} \mathrm{O}$ on the estimation of lung volumes and stereologically assessed parameters that describe the lung structure in developing mouse lungs. The data presented demonstrate that low $P_{\text {aw }}\left(10 \mathrm{cmH}_{2} \mathrm{O}\right)$ leads to heterogeneity in the unfolding of alveolar structures within the lungs, and that high $P_{\text {aw }}\left(30 \mathrm{cmH}_{2} \mathrm{O}\right)$ leads to an overestimation of the lung volume, and thus, affects the estimation of volume-dependent parameters, such as total alveoli number and gas-exchange surface area. Thus, these data support the use of a $P_{\text {aw }}$ of $20 \mathrm{cmH}_{2} \mathrm{O}$ for inflation fixation in morphometric studies on neonatal mouse lungs.
\end{abstract}

Keywords Airway pressure $\cdot$ Inflation fixation $\cdot$ Mouse $\cdot$ Lung volume $\cdot$ Lung development $\cdot$ Stereology

\section{Introduction}

Supplementary Information The online version contains supplementary material available at https://doi.org/10.1007/s0041 8-020-01951-0.

Rory E. Morty

rory.morty@mpi-bn.mpg.de

1 Department of Lung Development and Remodelling, Max Planck Institute for Heart and Lung Research, member of the German Center for Lung Research (DZL), Parkstrasse 1, 60231 Bad Nauheim, Germany

2 Department of Internal Medicine (Pulmonology), University of Giessen and Marburg Lung Center (UGMLC), member of the German Center for Lung Research (DZL), Aulweg 123, 35394 Giessen, Germany

3 Regenerative Medicine Program, The Ottawa Hospital Research Institute, 501 Smyth (Box 511), Ottawa, ON 1H 8L6, Canada
Lung organogenesis occurs over a protracted period in mammals that starts in the early embryonic period, and continues into adolescence (Schittny 2017). Over the course of lung organogenesis, marked changes occur in the cellular

4 Department of Cellular and Molecular Medicine, University of Ottawa, 451 Smyth Road, Ottawa, ON K1H 8M5, Canada

5 Centre for Paediatric and Adolescent Medicine, Heidelberg University Hospital, Im Neuenheimer Feld 430, 69120 Heidelberg, Germany

6 Our Lady's Hospital, MoathillCo. Meath, Navan C15 RK7Y, Ireland

7 Cardio Pulmonary Institute, Justus Liebig University Giessen, Klinikstrasse 33, Giessen, Germany

8 Institute for Lung Health (ILH), Justus Liebig University Giessen, Aulweg 130, Giessen, Germany 
and extracellular composition (Whitsett et al. 2019) and mechanical properties and architecture (Schittny 2017) of the lungs. The study of structural changes that occur during lung development rely on quantitative information about the lung structure, such as morphometric stereological methods (Weibel et al. 2007) that permit estimation of the density and number of alveoli, the gas-exchange surface area, and septal thickness, amongst other parameters.

The reliability of these estimations is critically dependent upon proper inflation of lungs during embedding and sectioning (Hsia et al. 2010). The airway pressure, $P_{\text {aw }}$, determines the extent of lung inflation, including the unfolding of alveolar structures within the lungs. Thus, selection of appropriate $P_{\text {aw }}$ is essential, as an optimal $P_{\text {aw }}$ will expandbut not distend-the lungs, and will unfold the alveolar structures within the lungs such that reliable and reproducible quantitative measurements are possible (Hsia et al. 2010). The plethora of studies [for example (Limjunyawong et al. 2015; Schulte et al. 2019)] that quantify elements of adult mouse lung structure have established $20-25 \mathrm{cmH}_{2} \mathrm{O}$ as an appropriate $P_{\text {aw }}$ for intratracheal instillation of fixative solutions. This approach is widely used to study the microscopic structure of adult healthy and diseased mouse lungs.

Increasing interest in the structural changes that occur during normal and abnormal development of immature lungs [reviewed in (Lignelli et al. 2019)] has stimulated efforts to quantify elements of the lung structure in newborn or immature, developing mice. Newborn and developing mouse lungs are structurally and functionally distinct from adult lungs, where, pronounced changes in the cellular and extracellular components of the lungs accompany lung maturation. Compared to adult lungs, the more cellular nature of developing septa (Ruiz-Camp et al. 2019) and less mature extracellular matrix (ECM) network (Mižíková and Morty 2015) in newborn lungs affect the compliance of the lungs and may render lungs more or less sensitive to distension by $P_{\mathrm{aw}}$. Additionally, the small size, larger tissue-to-air volume ratio, and high surface-to-volume ratio of developing mouse lungs might limit the ability of instilled fixative to properly enter the lung.

For these reasons, a side-by-side comparison of a $P_{\text {aw }}$ of 10,20 , and $30 \mathrm{cmH}_{2} \mathrm{O}$ was performed, where immature, developing mouse lungs were inflated at one of these three $P_{\text {aw }}$, and then subjected to lung volume estimation and stereological analysis. The data presented herein demonstrate that a comparatively low inflation fixation $P_{\text {aw }}$ of $10 \mathrm{cmH}_{2} \mathrm{O}$ results in heterogeneous unfolding of alveolar structures within the lungs, which impacts stereologically determined parameters to describe the lung structure. Similarly, a comparatively high inflation fixation $P_{\text {aw }}$ of $30 \mathrm{cmH}_{2} \mathrm{O}$ confounds estimation of lung volume, and hence, affects the reliability of volume-dependent stereologically determined parameters. Collectively, these data support the use of an
Fig. 1 Lung inflation and volume at variable airway pressures. a Lung inflation was considered complete when the cardiac lobe was fully inflated, and the most distal aspect of the cardiac lobe (arrow) projected maximally outwards. b The time required for maximum inflation of lungs with fixative at airway pressures $\left(P_{\text {aw }}\right)$ of 10 $\mathrm{cmH}_{2} \mathrm{O}, 20 \mathrm{cmH}_{2} \mathrm{O}$, and $30 \mathrm{cmH}_{2} \mathrm{O}$. c Gross morphology of mouse lungs harvested at postnatal day 14 and inflated with fixative at $P_{\text {aw }}$ of 10,20 , and $30 \mathrm{cmH}_{2} \mathrm{O}$; superimposed on 1-mm graph paper. Images are representative of the trends overserved in four other lungs per experimental group. Scale bar: $1 \mathrm{~cm}$. The $\mathbf{d}$ mouse body mass was measured, and e lung volume was estimated using Cavalieri's principle. Data reflect mean \pm S.D. ( $n=5$ lungs per experimental group). Closed inverted triangles denote female animals, closed circles denote male animals. Data comparisons were performed by one-way ANOVA with Tukey's post hoc test, with $P$ values $<0.05$ indicated. $L L$ left lung, $R L$ right lung

inflation fixation $P_{\text {aw }}$ of $20 \mathrm{cmH}_{2} \mathrm{O}$ in stereology studies of immature, developing mouse lungs.

\section{Materials and methods}

\section{Animal studies}

Animal procedures were conducted in accordance with local and national regulations. Newborn C57BL/6J mouse pups (Charles River, Sülzfeld, Germany) were maintained to postnatal day $(\mathrm{P}) 14$. Sex of the mouse pups was determined by visualization of external genitalia (Wolterink-Donselaar et al. 2009). Dams and pups were maintained on a 12-h/12-h light-dark cycle, and received food and water ad libitum.

\section{Animal studies}

Mouse pups were killed by administration of $500 \mathrm{mg} \cdot \mathrm{kg}^{-1}$ sodium pentobarbital (Narcoren; Bohringer, Ingelheim, Germany), via the intraperitoneal route. The thoracic cavity was exposed by midsternal thoracotomy and dissection of the diaphragm at the point of contact with the ribcage. Tracheostomy was undertaken with a $22 \mathrm{G}$ blunt-ended cannula (CML Supply, Lexington, U.S.A.), which was fixed in place with a USP 4/0 non-absorbable surgical suture (Supramid, St. Vith, Belgium), as depicted in Fig. 1a. The lungs were fixed by intratracheal instillation of $1.5 \%(\mathrm{~m} / \mathrm{v})$ paraformaldehyde, $1.5 \%(\mathrm{~m} / \mathrm{v})$ glutaraldehyde in $150 \mathrm{mM}$ HEPES, $\mathrm{pH}$ 7.4. Three groups of five mouse pups each were used to compare, side-by-side, the impact of different $P_{\text {aw }}$ on the estimation of elements of the lung structure by design-based stereology. To this end, lungs were inflated with fixative at $P_{\text {aw }}$ of 10,20 and $30 \mathrm{cmH}_{2} \mathrm{O}$, and took between 35 and $75 \mathrm{~s}$ to inflate (Fig. 1b), depending on $P_{\mathrm{aw}}$. Lungs were considered fully inflated once no visible increase in lung expansion was noted, and when the cardiac lobe was sufficiently turgid to maximally project outwards from the thorax (Fig. 1a). After 
(A)

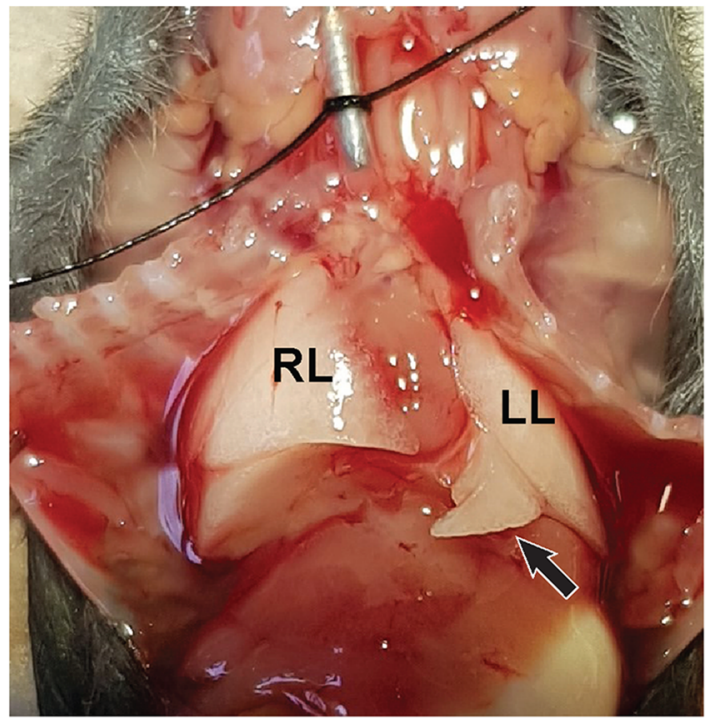

(C)
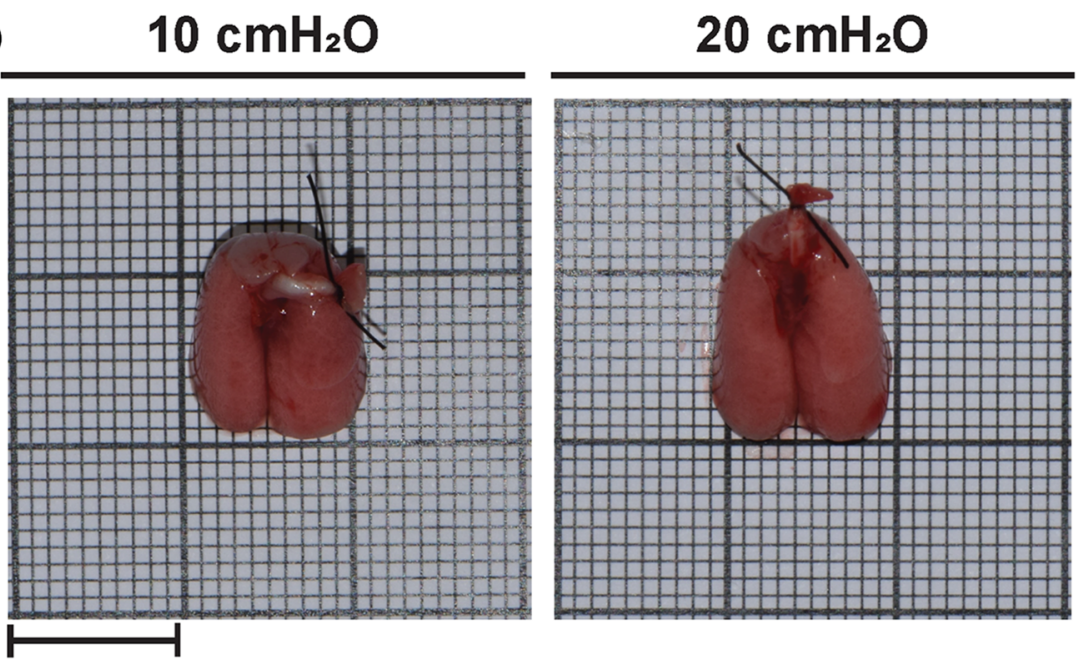
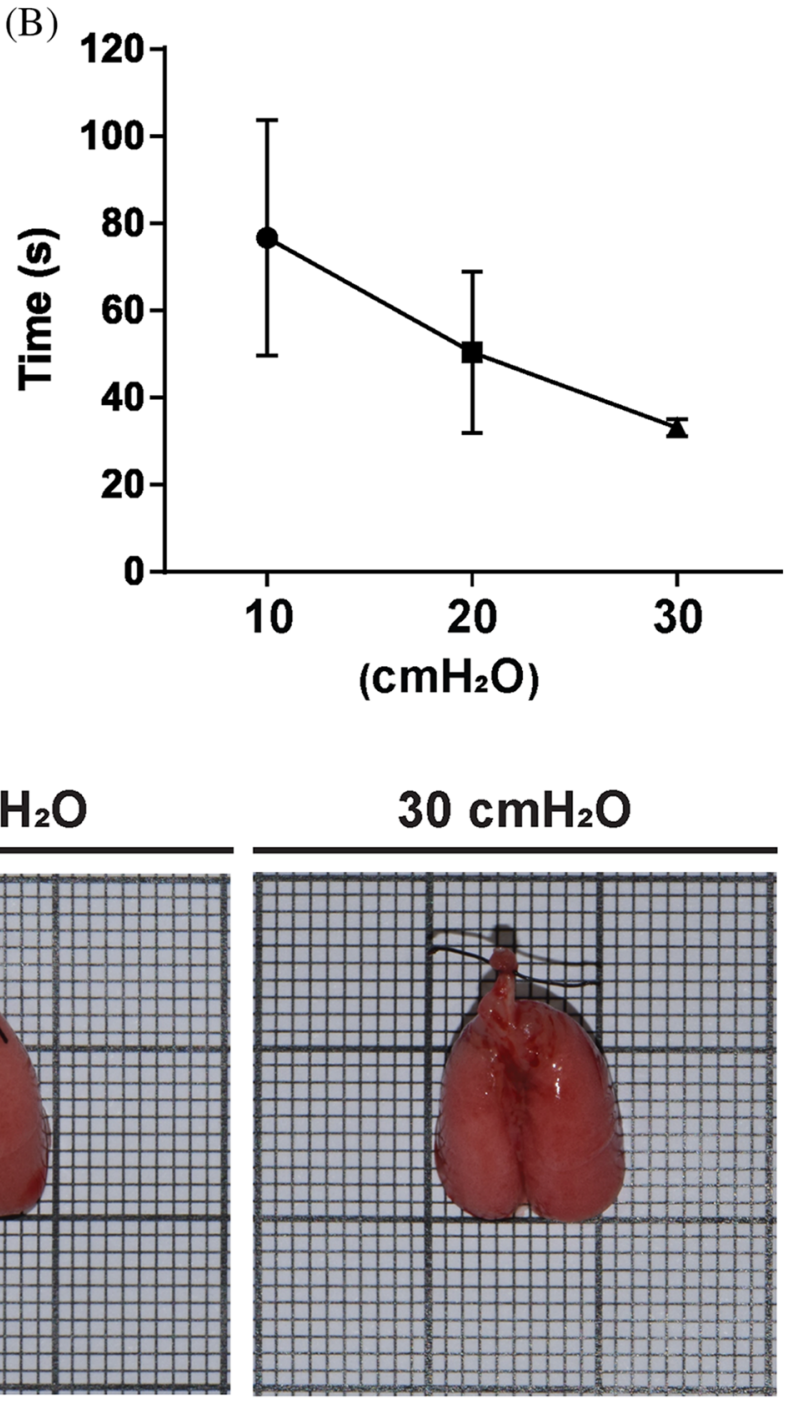

(D)

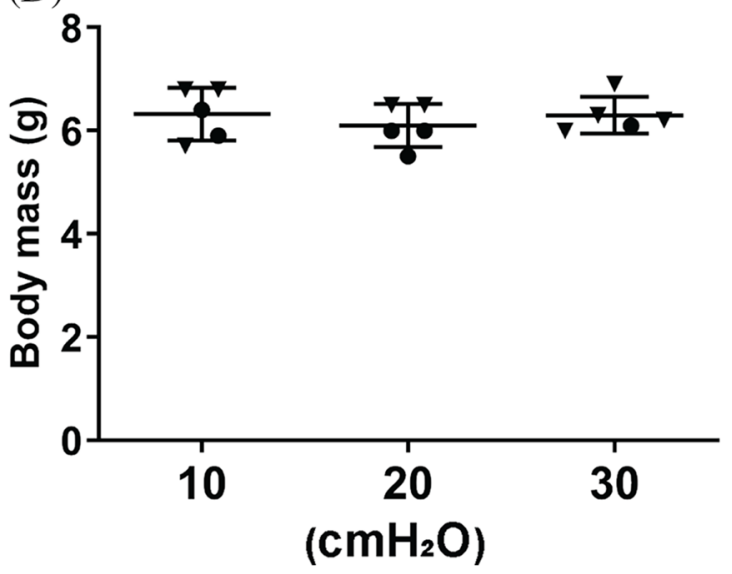

(E)

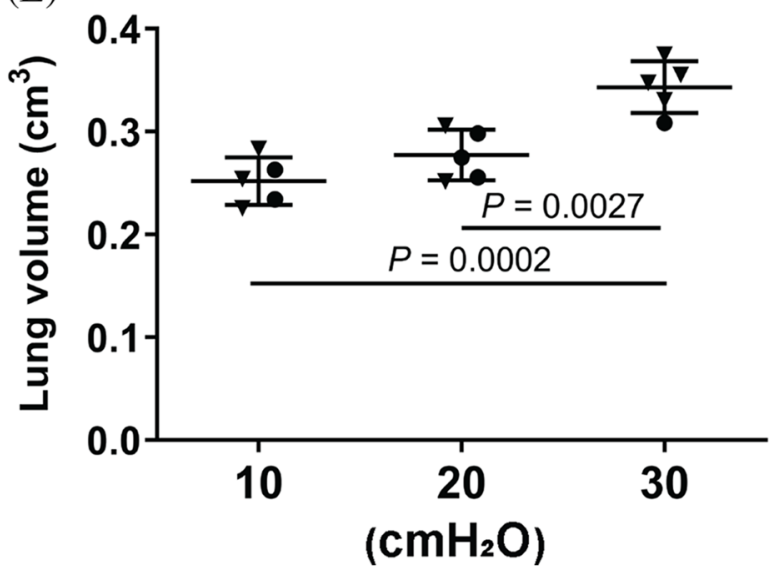


inflation, the tracheostomy needle was partially withdrawn, and the trachea was ligated with a suture as described above, below the placement of the tracheostomy suture. The lungs, heart, and thymus were removed en bloc, and placed in the same fixative solution for $24 \mathrm{~h}$ at $4{ }^{\circ} \mathrm{C}$ in a $5 \mathrm{ml}$ Eppendorf tube. Lungs were then dissected free of the heart and thymus and photographed on a background of 1-mm graph paper to record the gross anatomy (Fig. 1c).

Lung tissue was collected according to systematic uniform random sampling (Tschanz et al. 2014): Lungs were embedded in agarose [in $2 \%(\mathrm{~m} / \mathrm{v})$ agar-agar], and agar blocks were sectioned into $3-\mathrm{mm}$ slabs. Lung volume was estimated using Cavalieri's principle (Tschanz et al. 2011). Lung tissue was transferred from agar slabs into $15 \mathrm{ml}$ glass vials, and treated with $0.1 \mathrm{M}$ sodium cacodylate (Serva, Heidelberg, Germany; 15540.03), 1\% (m/v) osmium tetroxide (Roth, Karlsruhe, Germany; 8371.3), and 2.5\% (m/v) uranyl acetate (Serva, Darmstadt, Germany; 77870.01) in $\mathrm{ddH}_{2} \mathrm{O}$. Lung tissue was embedded in glycol methacrylate resin (Technovit 7100; Heareus Kulzer, Hanau, Germany; 64709003), which hardened over $48 \mathrm{~h}$ (Mühlfeld et al. 2013). Technovit blocks were sectioned at $2 \mu \mathrm{m}$. For estimation of total number of alveoli and alveolar density, every first and third section of a consecutive series of sections was collected and stained with Richardson's stain (Fehrenbach et al. 2008; Knust et al. 2009). For the analysis of additional parameters, four sections, representing every 10th section of a consecutive series in the same block, were collected and stained with Richardson's stain (Schneider and Ochs 2013). A NanoZoomer-XR C12000 Digital slide scanner (Hamamatsu Photomics Deutschland, Herrsching am Ammersee, Germany) collected digital images of tissue sections.

\section{Design-based stereology}

Analysis of lung structure was performed using the principles of design-based stereology that have been extensively reviewed for adult mouse lungs (Mühlfeld and Ochs 2013; Ochs and Mühlfeld 2013; Mühlfeld et al. 2015), in accordance with American Thoracic Society/European Respiratory Society guidelines for quantitative assessment of lung structure (Hsia et al. 2010), described in detail previously (Pozarska et al. 2017; Schneider et al. 2017; Wagener et al. 2020). For the estimation of alveolar density and alveolar number, one pair of sections was selected for analysis at a 3 and $10 \%$ coverage of the regions of interest of each section. For estimation of surface density, gas-exchange surface area, arithmetic mean septal thickness, and mean linear intercept (MLI), four sections per tissue block were selected for analysis, at 3 and $6 \%$ coverage of the regions of interest of each section; except for estimation of parenchymal volume, where a $10 \%$ coverage of the region of interest of each section was used.

\section{Statistics and stereological precision}

Data are presented as mean \pm SD. Differences were assessed by one-way ANOVA with Tukey's post hoc test for multiple comparisons. $P$ values ${ }^{<} 0.05$ were regarded as significant. Statistical analyses were performed with GraphPad Prism v. 8.4.2. The presence of statistical outliers was tested by Grubbs' test, and none were found. The coefficient of error (CE), the coefficient of variation $(\mathrm{CV})$ and the quotient $\mathrm{CE}^{2} /$ $\mathrm{CV}^{2}$ were calculated for each stereological parameter, where $\mathrm{a} \mathrm{CE}^{2} / \mathrm{CV}^{2}<0.5$ validated the precision of the measurements (Tables 1 and 2). To describe the variance within hydrostatic $P_{\text {aw }}$ groups comparing 3\% versus $10 \%$ (for alveoli number and alveolar density) or $3 \%$ versus $6 \%$ (for all other stereology parameters) coverage of the regions of interest, the absolute value of the difference between the two mean values of interest was calculated.

\section{Results and discussion}

For the stereological analysis of distal lung structure, lungs from experimental animals can be fixed by intratracheal instillation of fixative (Mühlfeld and Ochs 2013; Ochs and Mühlfeld 2013). The objective of the present study was to determine whether a $P_{\text {aw }}$ of $20 \mathrm{cmH}_{2} \mathrm{O}$ for inflation fixation-the $P_{\text {aw }}$ employed in studies with mature, adult mouse lungs - is also suitable for the stereological analysis of immature, developing mouse lungs.

This is important, since in the words of Drs. Wheeler, Wing and Zingarelli: "Children are not small adults!" (Wheeler et al. 2011). The compliance of the respiratory system diminishes during development, concomitant with the evolution of mechanical properties of the parenchyma and the airways (Sly et al. 2005). The lungs of children and adolescents have fewer alveoli compared to adults, which increase in number during early life and adolescence (Herring et al. 2014), to $\approx 480$ million alveoli in adults (Ochs et al. 2004). The alveoli are smaller in infants, and are approximately double in size in adult lungs (Zeman and Bennett 2006). Parallel trends in increasing alveoli number and decreasing alveoli size have also been noted during postnatal growth in mice (Pozarska et al. 2017) and rats (Tschanz et al. 2014). Pertinent to the present study, at the widely employed P14 endpoint in studies on normal and abnormal postnatal lung development in mice (Nardiello et al. 2017), neither the progressively increasing alveolar density, nor the progressively decreasing mean alveolar volumes, have plateaued out at their respective adult values (Pozarska et al. 2017). Thus, it was a matter of concern that the different structural and functional properties of immature mouse lungs may result in tissue distortion by $P_{\text {aw }}$ conventionally used for instillationfixation of adult mouse lungs. 


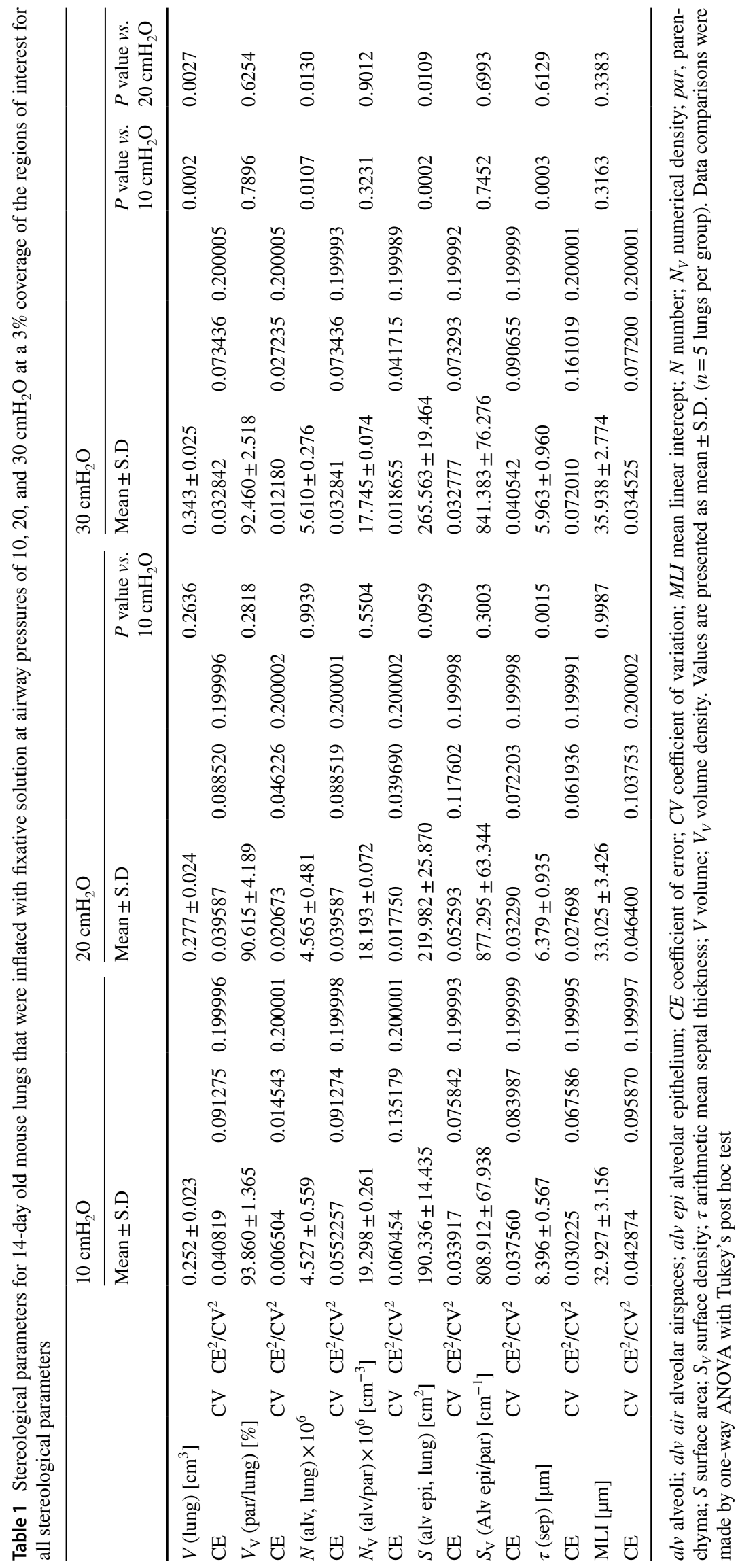




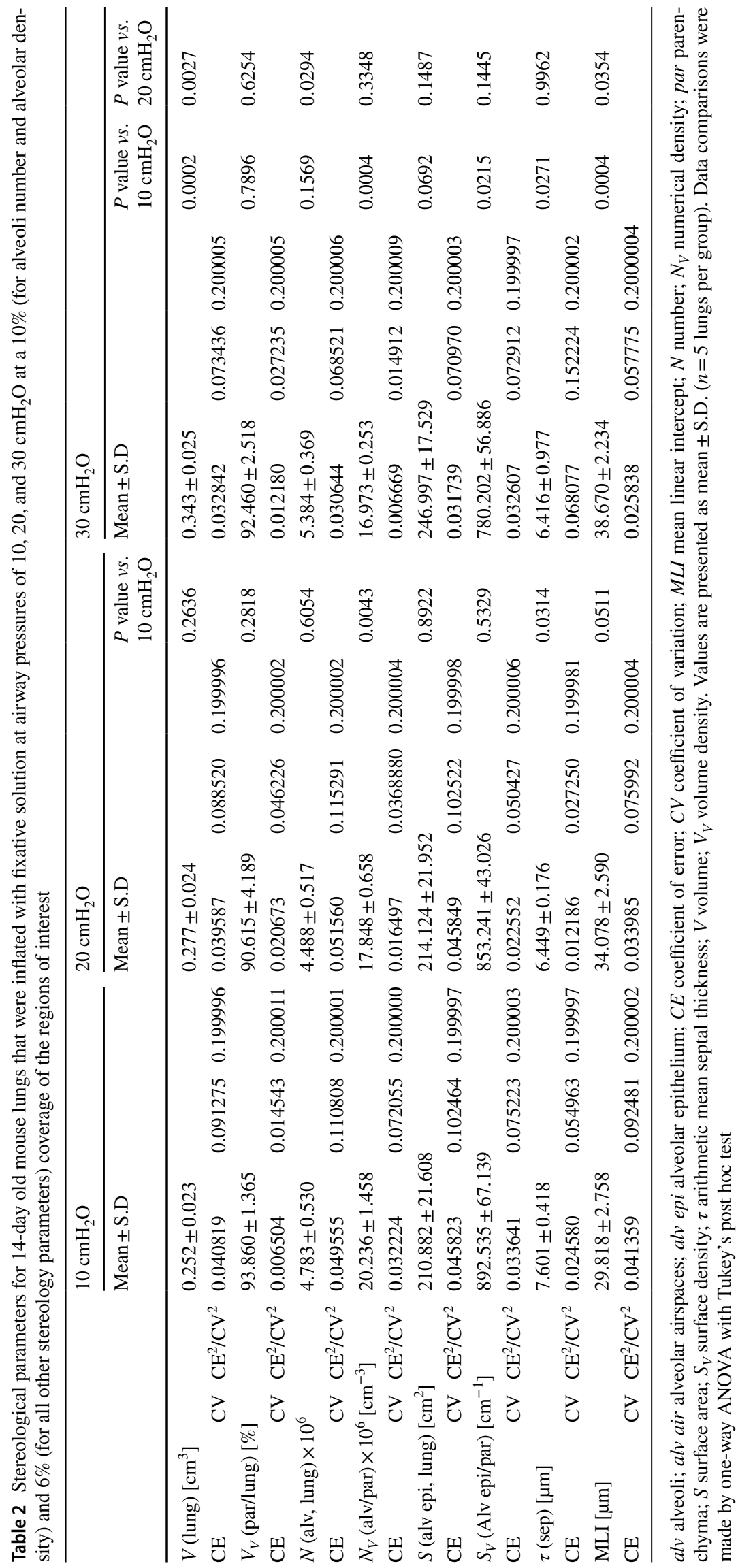


This concern has already been raised in studies on human lung disease modeled in mice that are characterized by loss of parenchymal tissue, such as modeling of emphysema in adult mice. In those studies, the airspaces of a disease lung with reduced elastic recoil will exhibit increased expansion over those in healthy lungs, which would stretch the alveolar septa. Thus, information gleaned about airspace enlargement and septal thickness would be confounded by the degree of inflation (Mühlfeld and Ochs 2013). Indeed, it has been noted that the estimation of the MLI strongly depends on the inflation status of the lung, where suboptimal inflation represents a key pitfall of the MLI parameter (Knudsen et al. 2010; Mühlfeld et al. 2015). As such, the $P_{\text {aw }}$ used for inflation fixation in mature, adult mouse lungs may not be suitable for the inflation fixation of immature, developing mouse lungs, given the different mechanical properties of the immature lung tissue.

A spectrum of $P_{\text {aw }}$ are routinely employed for the instillation fixation of adult mouse lungs, including $20 \mathrm{cmH}_{2} \mathrm{O}$
(Schulte et al. 2019) and $25 \mathrm{cmH}_{2} \mathrm{O}$ (Limjunyawong et al. 2015) which represent the recommended pressure range $\left(20-25 \mathrm{cmH}_{2} \mathrm{O}\right)$ for fixative instillation postmortem in adult mouse lungs (Hsia et al. 2010). In the present study, three different $P_{\text {aw }}$ were selected for instillation fixation of P14 mouse lungs with HEPES-buffered paraformaldehyde/glutaraldehyde: $10 \mathrm{cmH}_{2} \mathrm{O}, 20 \mathrm{cmH}_{2} \mathrm{O}$, and $30 \mathrm{cmH}_{2} \mathrm{O}$ (Fig. 1c). Inflation of the lungs was considered complete when the lungs were no longer visibly inflating, and when the cardiac lobe was sufficiently turgid to maximally project outwards from the thorax (Fig. 1a). Using these criteria, the time for complete inflation was longest $(\approx 75 \mathrm{~s})$ using $10 \mathrm{cmH}_{2} \mathrm{O} P_{\text {aw }}$, and shortest $\left(\approx 35 \mathrm{~s}\right.$ ) using $30 \mathrm{cmH}_{2} \mathrm{O}$ (Fig. 1b).

Mice of comparable body masses $(6.2 \pm 0.4 \mathrm{~g})$ were employed for these studies (Fig. 1d), given that lung volume may depend on body mass (Pozarska et al. 2017). As such, all 15 mice employed in the study were expected to exhibit similar lung volumes. The lung volumes estimated for the $10 \mathrm{cmH}_{2} \mathrm{O}(0.25 \pm 0.023 \mathrm{~g})$ and $20 \mathrm{cmH}_{2} \mathrm{O}(0.27 \pm 0.025 \mathrm{~g})$
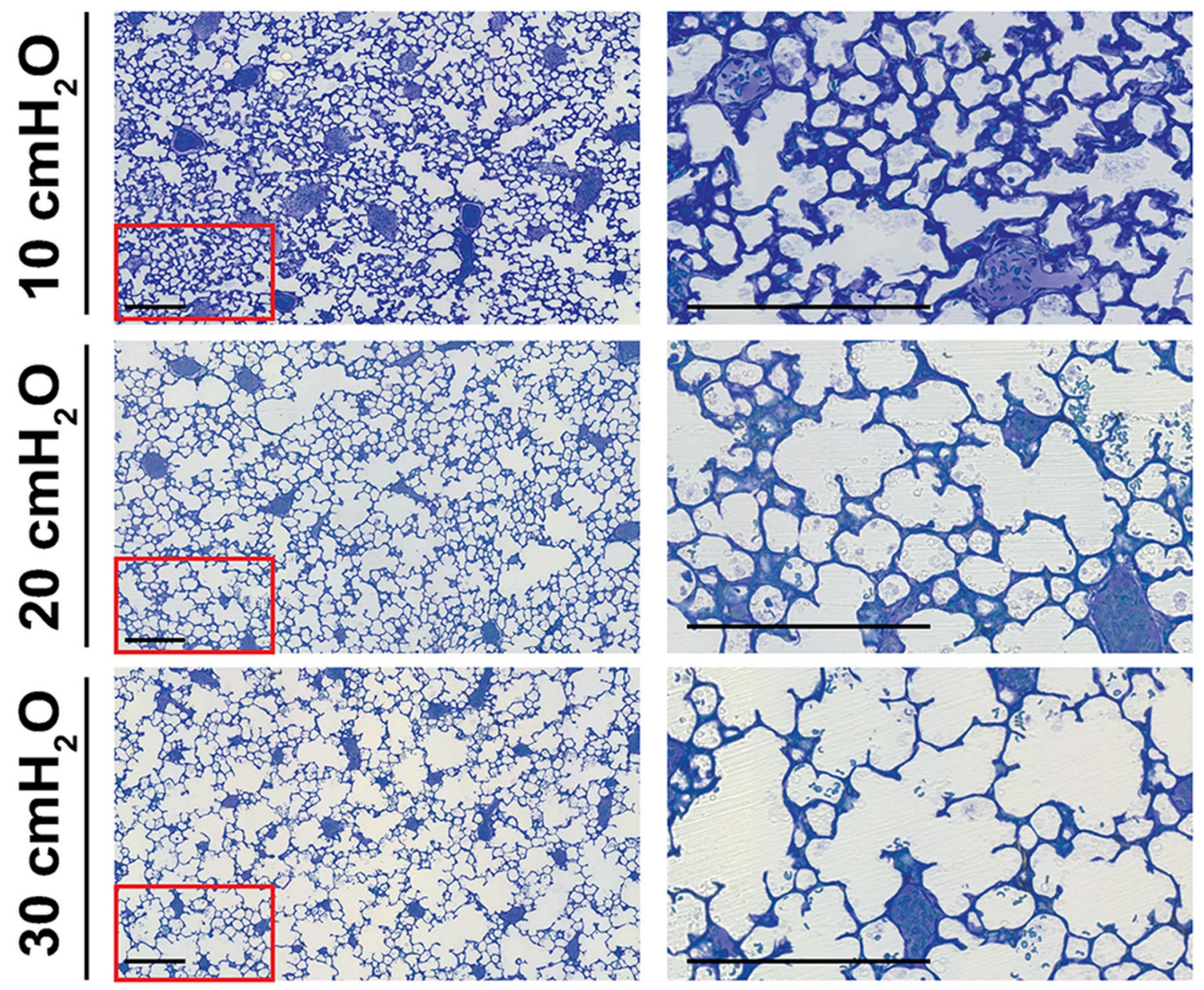

Fig. 2 Distal lung structure at variable airway pressures. Distal lung structure was visualized in plastic-embedded lung tissue stained with Richardson's stain, after lung inflation with fixative at airway pres- sures of 10,20 , and $30 \mathrm{cmH}_{2} \mathrm{O}$. The area demarcated with a red frame in the images at left are presented at higher magnification at right. Scale bar: $200 \mu \mathrm{m}$ 
groups were comparable (Fig. 1e). However, the $30 \mathrm{cmH}_{2} \mathrm{O}$ group exhibited higher lung volumes $(0.34 \pm 0.025 \mathrm{~g}$; Fig. 1e). These data suggested that the higher $P_{\text {aw }}$ of $30 \mathrm{cmH}_{2} \mathrm{O}$ may have overinflated the lungs.

Visual inspection of plastic-embedded lung tissue stained with Richardson's stain suggested that the alveolar density was highest in the $10 \mathrm{cmH}_{2} \mathrm{O}$ group and lowest in the $30 \mathrm{cmH}_{2} \mathrm{O}$ group (Fig. 2, left-hand column of images). Additionally, the septa appeared thicker in the $10 \mathrm{cmH}_{2} \mathrm{O}$ group, compared with the $20 \mathrm{cmH}_{2} \mathrm{O}$ and $30 \mathrm{cmH}_{2} \mathrm{O}$ groups (Fig. 2, right-hand column of images). Examination of lung tissue sections at low magnification revealed a comparable pattern of uniform inflation in the $20 \mathrm{cmH}_{2} \mathrm{O}$ and $30 \mathrm{cmH}_{2} \mathrm{O}$ groups (Fig. S1). However, comparison of low-magnification images of lung tissue sections from the $20 \mathrm{cmH}_{2} \mathrm{O}$ group (Fig. 3a) and $10 \mathrm{cmH}_{2} \mathrm{O}$ group (Fig. 3b), revealed a heterogeneous pattern of inflation in the $10 \mathrm{cmH}_{2} \mathrm{O}$ group (compare Fig. $3 \mathrm{c}$ and d), where the detection of bridges was complicated by the compactness of the tissue in some regions of the lungs. This challenge presented by the $10 \mathrm{cmH}_{2} \mathrm{O}$ group is further evident in Fig. S2, where increasing the coverage [either from 3 to $10 \%$ (Fig. S2a, b) or from 3 to $6 \%$ (Fig. S2c-f)] markedly affected estimates of all stereological parameters. Collectively, these data suggest that a $P_{\text {aw }}$ of $10 \mathrm{cmH}_{2} \mathrm{O}$ is insufficient to properly inflate the distal lung, and that a $P_{\text {aw }}$ of $30 \mathrm{cmH}_{2} \mathrm{O}$ distends the lung structure by over-inflation.

Using design-based stereology to estimate parameters that describe the distal lung architecture, the alveolar density comparing the $10 \mathrm{cmH}_{2} \mathrm{O}, 20 \mathrm{cmH}_{2} \mathrm{O}$, and $30 \mathrm{cmH}_{2} \mathrm{O}$ groups was similar at $3 \%$ coverage (Fig. $4 a$ ). However, this observation did not reflect the trends noted by visual inspection of lung sections from these three experimental groups (Fig. 2). For this reason, alveolar density was re-assessed at $10 \%$ coverage, where the alveolar density of the $10 \mathrm{cmH}_{2} \mathrm{O}$ group was revealed to be higher than that of the $20 \mathrm{cmH}_{2} \mathrm{O}$ and $30 \mathrm{cmH}_{2} \mathrm{O}$ groups, most likely reflecting the heterogeneity of lung inflation in the $10 \mathrm{cmH}_{2} \mathrm{O}$ group (Fig. 3). The alveolar density comparing the $20 \mathrm{cmH}_{2} \mathrm{O}$ and $30 \mathrm{cmH}_{2} \mathrm{O}$ groups was unchanged irrespective of 3 or $10 \%$ coverage (Fig. 4a, b). However, a higher number of alveoli was estimated in lungs inflated at $30 \mathrm{cmH}_{2} \mathrm{O}$, most likely due to the increased volume estimated for those lungs (Fig. 1e), due to distension of the lungs at a $P_{\text {aw }}$ of $30 \mathrm{cmH}_{2} \mathrm{O}$.

Increasing the coverage of the regions of interest was instructive for a number of other parameters that describe the distal lung structure, where no differences in surface density were noted comparing the $10 \mathrm{cmH}_{2} \mathrm{O}, 20 \mathrm{cmH}_{2} \mathrm{O}$, and $30 \mathrm{cmH}_{2} \mathrm{O}$ groups assessed at $3 \%$ coverage (Fig. 5a). However, increasing coverage to $6 \%$ revealed a decreased surface density in the $30 \mathrm{cmH}_{2} \mathrm{O}$ group, which is consistent with lung distension in the $30 \mathrm{cmH}_{2} \mathrm{O}$ group (Fig. 5b). The increased lung volume estimated for the $30 \mathrm{cmH}_{2} \mathrm{O}$ group also impacted other volume-dependent parameters, such as gas-exchange surface area (which relates surface density to lung volume). At $3 \%$ coverage, while the estimated surface density for the $10 \mathrm{cmH}_{2} \mathrm{O}, 20 \mathrm{cmH}_{2} \mathrm{O}$, and $30 \mathrm{cmH}_{2} \mathrm{O}$ groups was constant, a higher gas-exchange surface area was estimated for the $30 \mathrm{cmH}_{2} \mathrm{O}$ group, again reflecting lung distension. At $6 \%$ coverage, the magnitude

\section{$20 \mathrm{cmH}_{2} \mathrm{O}$}

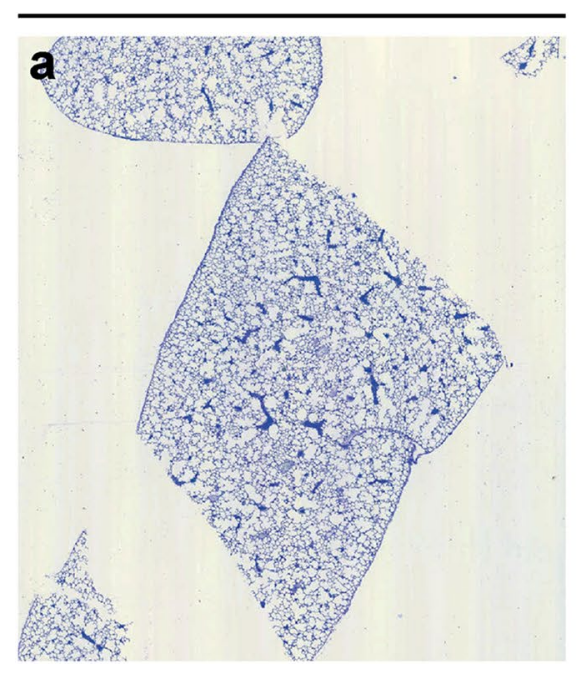

\section{$10 \mathrm{cmH}_{2} \mathrm{O}$}

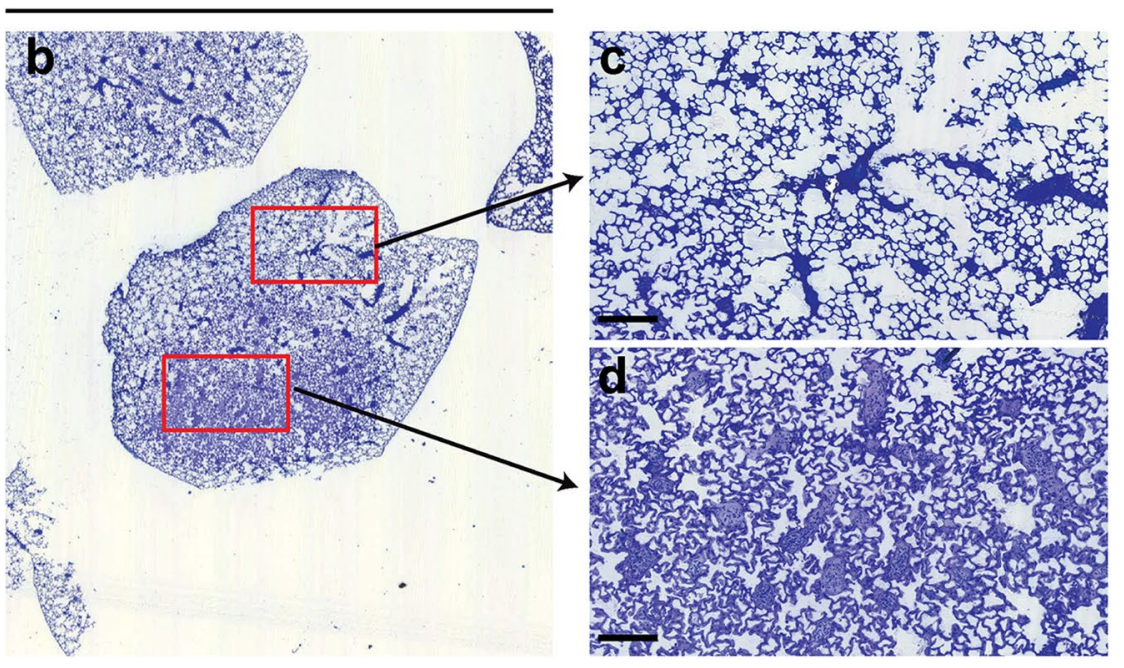

Fig. 3 Heterogeneity in distal lung structure at variable airway pressures. Low magnification images of lung sections after lung inflation with fixative at airway pressures of a $20 \mathrm{cmH}_{2} \mathrm{O}$ and $\mathbf{b} 10 \mathrm{cmH}_{2} \mathrm{O}$ are depicted. c, d Regions within (b) were selected (enclosed by the red frame) for presentation at higher magnification. Images are representative of trends overserved in four other lungs per experimental group. A panel including an image of a lung section after fixation inflation at $30 \mathrm{cmH}_{2} \mathrm{O}$ is included in Fig. S1. Scale bar: $200 \mu \mathrm{m}$ 


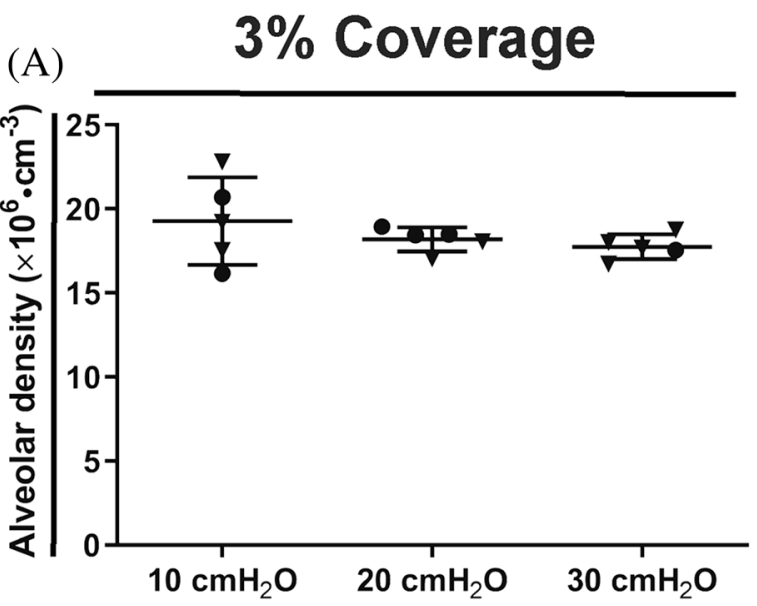

\section{(B) $10 \%$ Coverage}

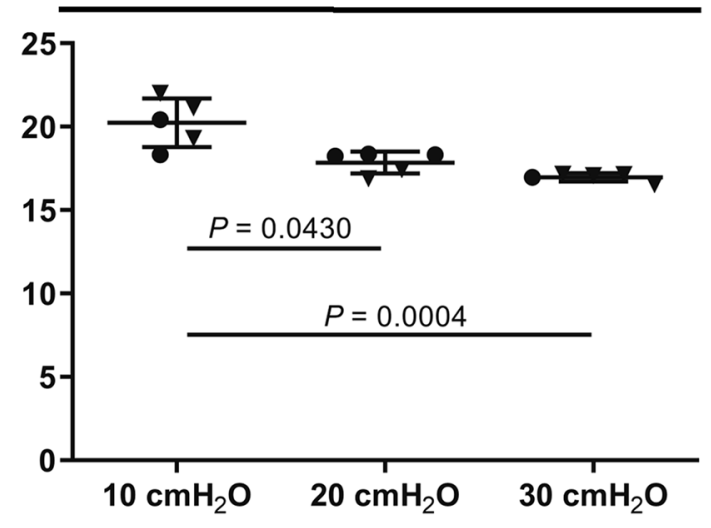

(B)

(C)

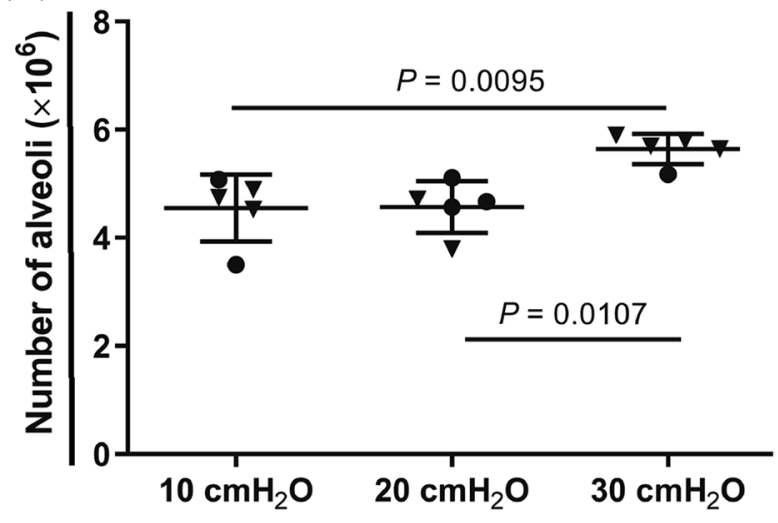

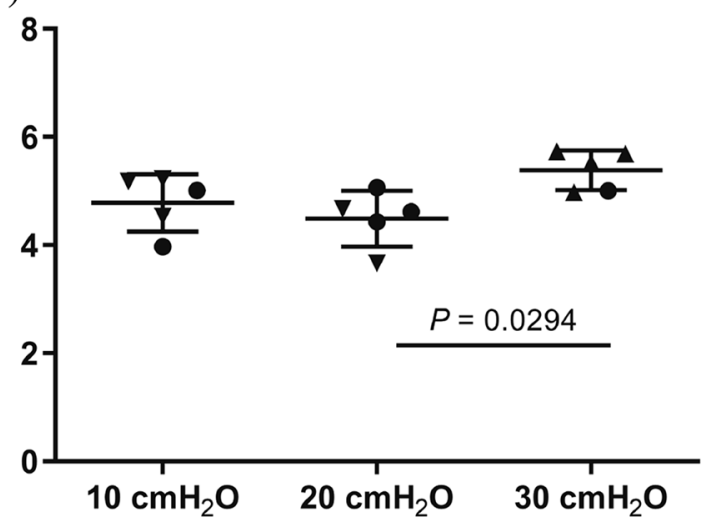

Fig. 4 Quantitative estimation of alveoli by design-based stereology. The $\mathbf{a}, \mathbf{b}$ alveolar density and $\mathbf{c}, \mathbf{d}$ number of alveoli per lung were estimated using design-based stereology at 3\% and 10\% coverage of the region of interest, after lung inflation-fixation at 10, 20, and $30 \mathrm{cmH}_{2} \mathrm{O}$. Data reflect mean \pm S.D. ( $n=5$ lungs per experimen-

of the gas-exchange surface area of the $30 \mathrm{cmH}_{2} \mathrm{O}$ group was still numerically greater-but not statistically significantly different from - the $10 \mathrm{cmH}_{2} \mathrm{O}$ and $20 \mathrm{cmH}_{2} \mathrm{O}$ groups (Fig. 5d; Table 2), which is attributable to a lower surface density having been estimated for the $30 \mathrm{cmH}_{2} \mathrm{O}$ group at $6 \%$ coverage (Fig. $5 \mathrm{~b}$ ). Increasing coverage from 3 to $6 \%$ also highlighted an increased MLI in the $30 \mathrm{cmH}_{2} \mathrm{O}$ group compared with the $20 \mathrm{cmH}_{2} \mathrm{O}$ group, which reflects the distension of the lungs in the $30 \mathrm{cmH}_{2} \mathrm{O}$ group. Similarly, at $6 \%$ coverage, the magnitude of the MLI was numerically lower in the $10 \mathrm{cmH}_{2} \mathrm{O}$ group compared with the $20 \mathrm{cmH}_{2} \mathrm{O}$ group (which approached statistical significance, $P=0.0511$; Fig. 5f), indicating underinflation of the lungs in the $10 \mathrm{cmH}_{2} \mathrm{O}$ group. That the lungs in the $10 \mathrm{cmH}_{2} \mathrm{O}$ group were underinflated is also supported by the increased arithmetic mean septal thickness noted at both 3 and $6 \%$ coverage in the lungs of the $10 \mathrm{cmH}_{2} \mathrm{O}$ group compared with the $20 \mathrm{cmH}_{2} \mathrm{O}$ and $30 \mathrm{cmH}_{2} \mathrm{O}$ groups (Fig. $5 \mathrm{~g}$, h). tal group). Closed inverted triangles denote female animals, closed circles denote male animals. Data comparisons were performed by one-way ANOVA with Tukey's post hoc test. Data comparisons with $P<0.05$ are indicated. Additional stereology parameters are presented in Tables 1 and 2

The objective of the present study was to determine the optimal $P_{\text {aw }}$ for the instillation fixation of developing mouse lungs. The data presented here suggest that low $P_{\text {aw }}$ (of $10 \mathrm{cmH}_{2} \mathrm{O}$ ) results in heterogeneous (under)inflation of lungs, where better and worse inflated areas confound stereological analyses. In contrast, high $P_{\text {aw }}\left(\right.$ of $\left.30 \mathrm{cmH}_{2} \mathrm{O}\right)$ leads to distortion of the lung volume by overinflation, leading to errors in the estimation of volume-dependent parameters, such as a total number of alveoli and gas-exchange surface area. As such, a $P_{\text {aw }}$ of $20 \mathrm{cmH}_{2} \mathrm{O}$ emerged as an optimal $P_{\text {aw }}$ for instillation fixation, which is supported by the consistently low variance in values of stereology parameters at a $P_{\text {aw }}$ of $20 \mathrm{cmH}_{2} \mathrm{O}$ [comparing 3\% versus $10 \%$ (Fig. 4) or $3 \%$ versus $6 \%$ (Fig. 5) coverage], compared to the 10 $\mathrm{cmH}_{2} \mathrm{O}$ and $30 \mathrm{cmH}_{2} \mathrm{O}$ groups (summarized in Fig. S2). As such, based on the data presented here, a $P_{\text {aw }}$ of $20 \mathrm{cmH}_{2} \mathrm{O}$ is recommended for the inflation fixation of the lungs of mouse pups. 


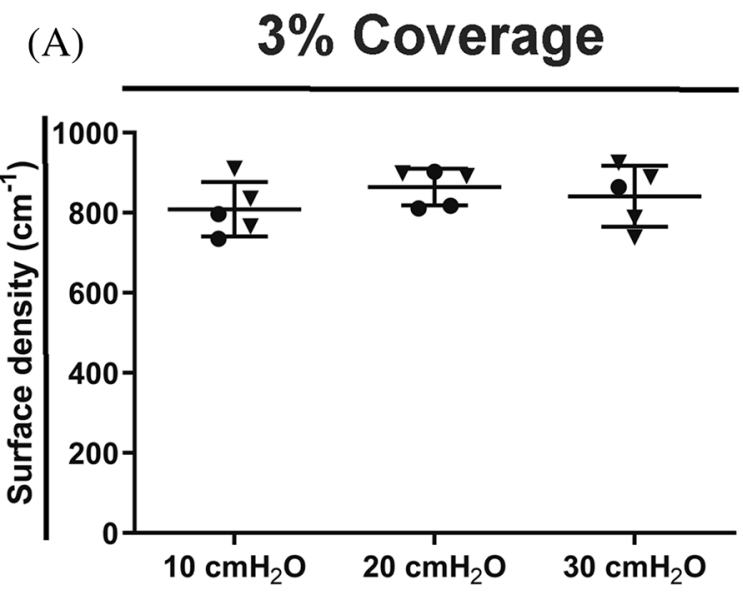

(B) $6 \%$ Coverage

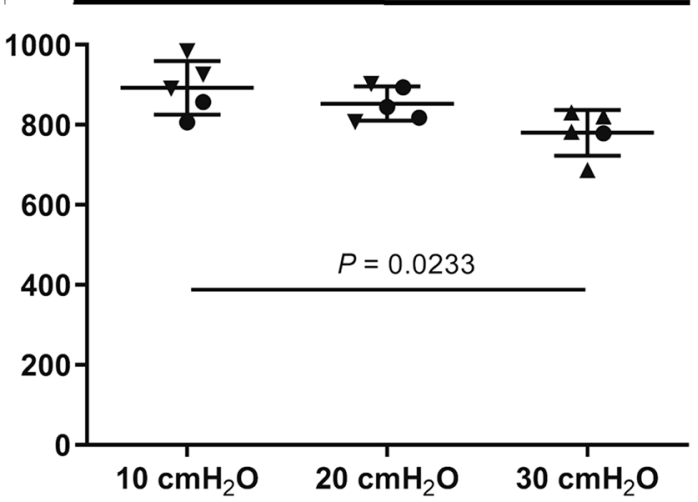

(D)

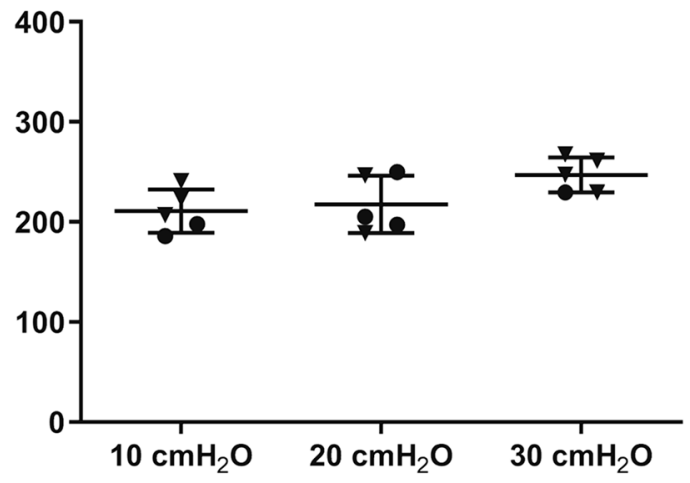

(F)

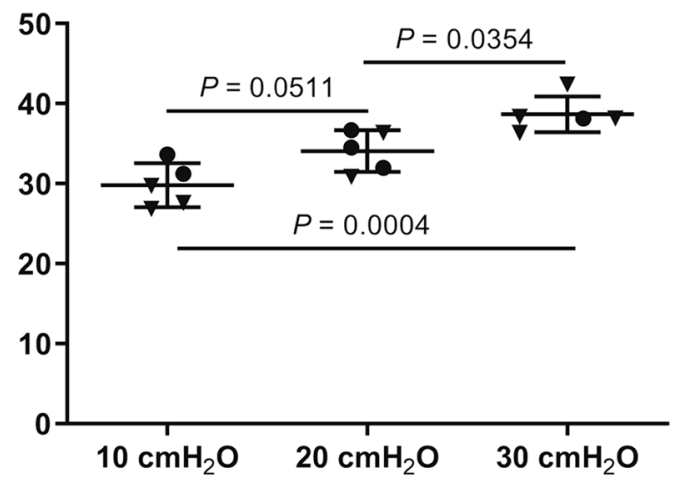

(H)

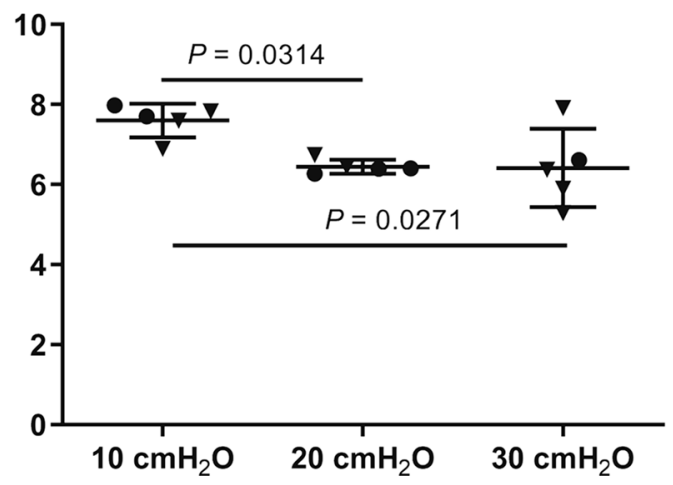


4Fig.5 Quantitative estimation of the distal lung architecture by design-based stereology. The $\mathbf{a}, \mathbf{b}$ surface density, $\mathbf{c}, \mathbf{d}$ gas-exchange surface area, e, f mean linear intercept, $\mathbf{g}, \mathbf{h}$ arithmetic mean septal thickness were estimated using a design-based stereology approach using 3 and $6 \%$ coverage of the region of interest, after lung inflation-fixation at 10,20 , and $30 \mathrm{cmH}_{2} \mathrm{O}$. Data reflect mean \pm S.D. $(n=5$ lungs per experimental group). Closed inverted triangles denote female animals, closed circles denote male animals. Data comparisons were performed by one-way ANOVA with Tukey's post hoc test. Data comparisons with $P$ values $<0.05$ are indicated. Additional stereology parameters are presented in Tables 1 and 2

By way of caveats, it is important to recognize that healthy lung tissue was employed in the present study, and thus, all three experimental groups would exhibit comparable elastic recoil. However, in the extension of these studies to the analysis of diseased lung tissue, where the parenchymal or elastin fraction of the tissue may be different between control and experimental groups, differences in elastic recoil between the groups is to be expected. This might affect the behavior of the lungs during and after instillation fixation; and during fixation, the retraction of lung tissue (und thus, lung volume) may occur to different degrees between control and experimental groups. This may be controlled for by performing Cavalieri estimates of lung volume before and after embedding.

Acknowledgements This work was supported by the Max Planck Society (WS and REM); the German Center for Lung Research (Deutsches Zentrum für Lungenforschung; DZL) (IV, SH, WS, and REM), the German Research Foundation (Deutsche Forschungsgemeinschaft; DFG) through Excellence Cluster EXC2026 [390649896] (IV, SH, WS, and REM), Collaborative Research Center SFB1213 [268555672] (WS and REM), Clinical Research Unit KFO309 [284237345] (IV, SH, WS, and REM), and individual research grants Mo 1789/1-1 [160966624] and Mo 1789/4-1 [420759458] (REM).

Author contributions DPB, DM, CN, WS, and REM conceived the study; DPB, DM, IV, TP, and DESS performed experiments; DPB, DM, IV, TP, DESS, CN, IV, SH, WS, KA, and REM analysed data; $\mathrm{DPB}, \mathrm{DM}$, and REM wrote the manuscript.

Funding Open Access funding enabled and organized by Projekt DEAL.

\section{Compliance with ethical standards}

Conflict of interest All authors declare the absence of conflict of interest.

Ethical approval All animal procedures were conducted in accordance with local and national regulations.

Open Access This article is licensed under a Creative Commons Attribution 4.0 International License, which permits use, sharing, adaptation, distribution and reproduction in any medium or format, as long as you give appropriate credit to the original author(s) and the source, provide a link to the Creative Commons licence, and indicate if changes were made. The images or other third party material in this article are included in the article's Creative Commons licence, unless indicated otherwise in a credit line to the material. If material is not included in the article's Creative Commons licence and your intended use is not permitted by statutory regulation or exceeds the permitted use, you will need to obtain permission directly from the copyright holder. To view a copy of this licence, visit http://creativecommons.org/licenses/by/4.0/.

\section{References}

Fehrenbach H, Voswinckel R, Michl V, Mehling T, Fehrenbach A, Seeger W, Nyengaard JR (2008) Neoalveolarisation contributes to compensatory lung growth following pneumonectomy in mice. Eur Respir J 31:515-522. https://doi.org/10.1183/09031 936.00109407

Herring MJ, Putney LF, Wyatt G, Finkbeiner WE, Hyde DM (2014) Growth of alveoli during postnatal development in humans based on stereological estimation. Am J Physiol Lung Cell Mol Physiol 307:L338-344. https://doi.org/10.1152/ajplung.00094.2014

Hsia CC, Hyde DM, Ochs M, Weibel ER, ATS/ERS Joint Task Force on Quantitative Assessment of Lung Structure (2010) An official research policy statement of the American Thoracic Society/European Respiratory Society: standards for quantitative assessment of lung structure. Am J Respir Crit Care Med 181:394-418. https ://doi.org/10.1164/rccm.200809-1522ST

Knudsen L, Weibel ER, Gundersen HJ, Weinstein FV, Ochs M (2010) Assessment of air space size characteristics by intercept (chord) measurement: an accurate and efficient stereological approach. J Appl Physiol (1985) 108:412-421. https://doi.org/10.1152/jappl physiol.01100.2009

Knust J, Ochs M, Gundersen HJ, Nyengaard JR (2009) Stereological estimates of alveolar number and size and capillary length and surface area in mice lungs. Anat Rec (Hoboken) 292:113-122. https://doi.org/10.1002/ar.20747

Lignelli E, Palumbo F, Myti D, Morty RE (2019) Recent advances in our understanding of the mechanisms of lung alveolarization and bronchopulmonary dysplasia. Am J Physiol Lung Cell Mol Physiol 317:L832-L887. https://doi.org/10.1152/ajplung.00369.2019

Limjunyawong N, Mock J, Mitzner W (2015) Instillation and fixation methods useful in mouse lung cancer research. J Vis Exp. https:// doi.org/10.3791/52964

Mižíková I, Morty RE (2015) The extracellular matrix in bronchopulmonary dysplasia: target and source. Front Med (Lausanne) 2:91. https://doi.org/10.3389/fmed.2015.00091

Mühlfeld C, Ochs M (2013) Quantitative microscopy of the lung: a problem-based approach. Part 2: stereological parameters and study designs in various diseases of the respiratory tract. Am J Physiol Lung Cell Mol Physiol 305:L205-221. https://doi. org/10.1152/ajplung.00427.2012

Mühlfeld C, Knudsen L, Ochs M (2013) Stereology and morphometry of lung tissue. Methods Mol Biol 931:367-390. https://doi. org/10.1007/978-1-62703-056-4_18

Mühlfeld C, Hegermann J, Wrede C, Ochs M (2015) A review of recent developments and applications of morphometry/stereology in lung research. Am J Physiol Lung Cell Mol Physiol 309:L526-L536. https://doi.org/10.1152/ajplung.00047.2015

Nardiello C, Mižíková I, Morty RE (2017) Looking ahead: where to next for animal models of bronchopulmonary dysplasia? Cell Tissue Res 367:457-468. https://doi.org/10.1007/s00441-016-2534-3

Ochs M, Mühlfeld C (2013) Quantitative microscopy of the lung: a problem-based approach. Part 1: basic principles of lung stereology. Am J Physiol Lung Cell Mol Physiol 305:L15-22. https://doi. org/10.1152/ajplung.00429.2012 
Ochs M, Nyengaard JR, Jung A, Knudsen L, Voigt M, Wahlers T, Richter J, Gundersen HJ (2004) The number of alveoli in the human lung. Am J Respir Crit Care Med 169:120-124. https:// doi.org/10.1164/rccm.200308-1107OC

Pozarska A, Rodríguez-Castillo JA, Surate Solaligue DE, Ntokou A, Rath P, Mižíková I, Madurga A, Mayer K, Vadász I, Herold S, Ahlbrecht K, Seeger W, Morty RE (2017) Stereological monitoring of mouse lung alveolarization from the early postnatal period to adulthood. Am J Physiol Lung Cell Mol Physiol 312:L882L895. https://doi.org/10.1152/ajplung.00492.2016

Ruiz-Camp J, Quantius J, Lignelli E, Arndt PF, Palumbo F, Nardiello C, Surate Solaligue DE, Sakkas E, Mizikova I, Rodríguez-Castillo JA, Vadász I, Richardson WD, Ahlbrecht K, Herold S, Seeger W, Morty RE (2019) Targeting miR-34a/Pdgfra interactions partially corrects alveologenesis in experimental bronchopulmonary dysplasia. EMBO Mol Med. https://doi.org/10.15252/emmm.20180 9448

Schittny JC (2017) Development of the lung. Cell Tissue Res 367:427444. https://doi.org/10.1007/s00441-016-2545-0

Schneider JP, Ochs M (2013) Stereology of the lung. Methods Cell Biol 113:257-294. https://doi.org/10.1016/B978-0-12-40723 9-8.00012-4

Schneider JP, Arkenau M, Knudsen L, Wedekind D, Ochs M (2017) Lung remodeling in aging surfactant protein $\mathrm{D}$ deficient mice. Ann Anat 211:158-175. https://doi.org/10.1016/j.aanat.2017.01.013

Schulte H, Muhlfeld C, Brandenberger C (2019) Age-related structural and functional changes in the mouse lung. Front Physiol 10:1466. https://doi.org/10.3389/fphys.2019.01466

Sly PD, Flack FS, Hantos Z (2005) Respiratory mechanics in infants and children. In: Hamid Q, Shannon J, Martin J (eds) Physiologic basis of respiratory disease. Hamilton, Ontario, BC Decker, pp $49-54$

Tschanz SA, Burri PH, Weibel ER (2011) A simple tool for stereological assessment of digital images: the STEPanizer. J Microsc 243:47-59. https://doi.org/10.1111/j.1365-2818.2010.03481.x
Tschanz SA, Salm LA, Roth-Kleiner M, Barre SF, Burri PH, Schittny JC (2014) Rat lungs show a biphasic formation of new alveoli during postnatal development. J Appl Physiol (1985) 117:89-95. https://doi.org/10.1152/japplphysiol.01355.2013

Tschanz S, Schneider JP, Knudsen L (2014) Design-based stereology: planning, volumetry and sampling are crucial steps for a successful study. Ann Anat 196:3-11. https://doi.org/10.1016/j.aanat .2013.04.011

Wagener I, Jungen M, von Horsten S, Stephan M, Schmiedl A (2020) Postnatal morphological lung development of wild type and CD26/DPP4 deficient rat pups in dependency of LPS exposure. Ann Anat 229:151423. https://doi.org/10.1016/j.aanat.2019.15142 3

Weibel ER, Hsia CC, Ochs M (2007) How much is there really? Why stereology is essential in lung morphometry. J Appl Physiol (1985) 102:459-467. https://doi.org/10.1152/japplphysiol.00808 .2006

Wheeler DS, Wong HR, Zingarelli B (2011) Pediatric Sepsis-Part I: "Children are not small adults!" Open Inflamm J 4:4-15. https:// doi.org/10.2174/1875041901104010004

Whitsett JA, Kalin TV, Xu Y, Kalinichenko VV (2019) Building and regenerating the lung cell by cell. Physiol Rev 99:513-554. https ://doi.org/10.1152/physrev.00001.2018

Wolterink-Donselaar IG, Meerding JM, Fernandes C (2009) A method for gender determination in newborn dark pigmented mice. Lab Anim (NY) 38:35-38. https://doi.org/10.1038/laban0109-35

Zeman KL, Bennett WD (2006) Growth of the small airways and alveoli from childhood to the adult lung measured by aerosol-derived airway morphometry. J Appl Physiol (1985) 100:965-971. https ://doi.org/10.1152/japplphysiol.00409.2005

Publisher's Note Springer Nature remains neutral with regard to jurisdictional claims in published maps and institutional affiliations. 